\title{
Bank Performance versus Recession Indicators: A Linear Cointegration Approach
}

\author{
Ashamu Sikiru Oyerinde ${ }^{1}$ \\ ${ }^{1}$ Department of Banking and Finance, Faculty of Management Sciences, Lagos State University, Ojo, Lagos. \\ Correspondence: Department of Banking and Finance, Faculty of Management Sciences, Lagos State University, \\ Ojo, Lagos, Tel: +2348033713969, E-mail: soyerinde2012@gmail.com
}

Received: July 13, 2017

Accepted: July 15, 2017

Online Published: July 17, 2017

\begin{abstract}
In this study, the researcher provides an empirical investigation of the nexus between banks' performance and recession indicators. A sample size of 35 years was selected on annual data. A linear cointegration method was adopted after accounting for seasonality through logarithmic transformation. The results revealed that indicators of recession-exchange rate, inflation and interest rate maintain long run relationship with bank performance, and evidence of long run influence was established. Furthermore, we discover that within the purview of short run dynamic situation, inflation influences banks' performance inversely, while exchange rate and interest rate increase with increase in banks' performance. We therefore conclude that banks' performance is driven by indicators of recession both in the short and in long run.
\end{abstract}

Keywords: Banks, exchange rate, inflation, interest rate and cointegration.

\section{Introduction}

Over the past decade, the credit quality of loan portfolios across most countries in the world remained relatively stable until the financial crises hit the global economy in 2007-2008. Since then, average bank asset quality deteriorated sharply due to the global economic recession. The fact that loan performance is tightly linked to the economic cycle is well known and not surprising. Yet the deterioration of loan performance was very uneven across countries. For example, the Baltic countries which stand out in cross-country comparisons of GDP performance during the crisis had very large increases in non-performing loans (NPLs) even when controlling for the severity of the recession.

Thus, the 2007-2009 global financial turmoil affected banking systems around the world, including Nigeria. Nevertheless, Nigerian banks have not performed relatively well. They for example, require capital injections at some point in time, and deposit guarantees have to be expanded. According to Kithinji and Waweru (2007), banking problems is back-dated as early as 1986 culminating in major bank failures (37 failed banks as at 1998) following the crises of 1986 to $1989,1993 / 1994$ and 1998; they attributed these crises to NPLs which is due to the interest rate spread. According to (McNulty et al 2001), controlling NPLs is very important for both the performance of an individual bank and the economy's financial environment. Due to the nature of their business, 
Ashamu Sikiru Oyerinde

commercial banks expose themselves to the risks of default from borrowers. Prudent credit risk assessment and creation of adequate provisions for bad and doubtful debts can cushion the banks risk. It is established that when the level of nonperforming loans is very high, the provisions are not adequately protected (Waweru and Kalani, 2009). The occurrence of banking crises has often been associated with a massive accumulation of nonperforming assets which can account for a sizable share of total assets of insolvent banks and financial institutions. Therefore, the causes of loan defaults should be established so as to reduce the level of nonperforming loans.

From the foregoing, it seems there is negative relationship between recession and banks' performance. However, management of recession in an economy helps improve the financial performance of banks, as interest on loans is the biggest income of banks, and increase the liquidity position of banks, protect the bank reputation and reduce loan losses. Also, Golden, Sam and Harry (1993) emphasized that since one of the most important aspects of lending is determining the customer desire to repay the loan, information in the credit file will give the credit officer document on the customer's repayment history. This is accomplished with the fact that commercial banks have measures in place to guard against loans, taking mortgages on landed properties, stock, bonds and other securities to fall on in time of default. This was debunked by Samuel (2011) who claimed that loan default has become an inevitable part of the banking or lending business in a recessive economy, there is high default risk because the income of borrowers has to be reduced. Accordingly leading to repression situation and consequently reducing the ability to honor obligations at maturities. The argument perhaps is do banks drive well in recession, when exchange rate and interest rate increase sporadically. Many studies have answered this question differently. This growing gap has inspired me to investigate the dynamic causations that exist between recession proxies and bank performance in Nigeria with the aim of justifying or expanding existing positions. The rest of the paper is organized as literature review, methodology and data, results, conclusion and recommendations

\section{Literature Review}

The Great Recession is strongly associated with the US real estate crisis and recent work has explored the link between real estate stresses and bank distress. Aubuchon and Wheelock (2010) find that both during the 2007-2010 and the 1987-92 episodes, bank failures were concentrated in regions with the largest declines in economic activity (as evident in declines in personal income or gross state product, and in increases in unemployment) and with the most severe stresses in the real estate market (as evident in declines in house prices and increases in delinquency rates). Beltratti and Stulz (2012) find that banks whose returns were more exposed to US real estate exhibited better stock performance during the crisis, but this effect they find to only be present in a subsample of very large banks (assets greater than $\$ 50$ billion).

New England experience of the early 1990s has shown that even well-capitalized banks can fail, as capital buffers deteriorate rapidly when banks approach failure (Peek and Rosengren (1997)). In a more recent paper, Berger and Bouwman (2013) exploit an exogenous source of variation in the stock of capital buffers to study the effect of capital on two dimensions of bank performance, probability of survival and market share, and find the effect to vary across banking crises, market crises, and normal times. In particular, capital increases the probability of survival and market share of smaller banks for all three types of crises, but improves the performance of medium and large banks primarily during banking crises. Though these studies advance our understanding ECB Working Paper 1779, April 2015, 9 of bank capital's primary function as the buffer that stands between bank survival and failure, they do not speak to the root causes of the losses that capital buffers are set to absorb. Bank failure is normally attributed to excessive risk-taking by banks, and some studies have 
Ashamu Sikiru Oyerinde

modeled bank risk as an outcome variable of managerial quality and/or corporate governance. Wheelock and Wilson (2000) show that during the 1984-1993 banking crisis banks with low managerial quality were more likely to fail and less likely to be acquired. Laeven and Levine (2009) use an international sample of banks to study the effect of conflicts of interest between managers and shareholders on risk-taking during the early 2000s. They find that banks with more powerful owners tend to take greater risks and also find the impact of banking regulations to vary with shareholder concentration.

Cole and White (2012) is the only study known to the author that identifies the composition of a bank's loan portfolio into real estate products as a relevant predictor of bank failure during the Great Recession. Cole and White (2012) decompose the bank's loan portfolio into various categories of real estate loans and show that exposure to commercial real estate loans, loans for construction and development projects, and multifamily mortgages increased the probability of failure relative to exposure to non-real estate loans. The authors do not find similar effects stemming from holdings of traditional mortgages or MBS, though the absence of an effect for MBS holdings is likely a result of their model not explicitly accounting for holdings of MBS.

Beltratti and Stulz (2012) confirm the findings of Laeven and Levine (2009) for the pre-crisis period, but challenge the view that poor bank governance was a major cause of the crisis by showing that banks with more shareholder-friendly boards performed significantly worse during the crisis. In addition, Fahlenbrach and Stulz (2011) find no evidence that banks with incentive structures which better aligned the interests of shareholders to those of the CEO performed better during the crisis. These studies identify agency-type drivers of bank risk, but, with the exception of Beltratti and Stulz (2012), abstract away from the specific ways in which risk-taking by bank management manifests itself in the choice of business model. Related research has addressed directly the question of whether certain business models were more prone to distress than others during the financial crisis of 2007-2008. Ratnovski and Huang (2009) examine bank performance on a sample of large OECD banks and show that higher levels of capital adequacy, deposit funding, and asset liquidity were associated with both a lower probability of government intervention and lower stock price declines. Altunbas, Manganelli and Marques-Ibanez (2012) use a sample of listed banks operating in the European Union and the United States, and explore several measures of realized bank risk to show that credit expansion, lower dependence on deposit-funding, larger size, and weaker capital buffers in the run up to the crisis accounted for higher ex-post levels of distress. Fahlenbrach, Prilmeier and Stulz (2012) identify the presence of persistence in bank risk, showing that stock return performance during the1998 crisis can predict stock return performance and the probability of failure during the Great Recession. The authors also show that reliance on short-term funding, high leverage, and high growth rates are all associated with poor bank performance in both crises. Beltratti and Stulz (2012) examine the determinants of stock return performance across an international sample of banks during the period from July 2007 to December 2008, and find that banks which were more dependent on wholesale funding and held less capital performed poorly during the crisis.

DeYoung and Torna (2013) focus on composition effects, and examine the degree to which the composition of a bank's income sources affected bank distress during the recent financial crisis. They show that for distressed banks the probability of bank failure increased with asset-based nontraditional activities (venture capital, investment banking and asset securitization), but declined with pure fee-based nontraditional activities (securities brokerage and insurance sales). DeYoung and Torna (2013) also show that banks with a substantial amount of asset-based nontraditional activities tended to take more risk on their traditional banking activities. 


\section{Methodology and Data}

\subsection{Model}

The model adopted in this study follows the approach of Ratnovski and Huang (2009) but with distinct focus on the link between bank asset and recessive factors (exchange rate, inflation and interest rate). With this objective, our specification is quite stance from Fahlenbrach, Prilmeier and Stulz (2012). Thus, our baseline VAR (P) relation can be represented in log form as.

$$
\begin{aligned}
& \operatorname{Inba}_{t}=a_{10}+\sum_{i=1}^{p} a_{1 i} \operatorname{Inba}_{t-i}+\sum_{i=1}^{p} b_{1 i} \operatorname{Inex}_{t-i}+\sum_{i=1}^{p} c_{1 i} \operatorname{Inint}_{t-i}+\sum_{i=1}^{p} d_{1 i} \operatorname{Ininf}_{t-i}+u_{1 t} \\
& \text { Inex }_{t}=a_{20}+\sum_{i=1}^{p} a_{2 i} \text { Inex }_{t-i}+\sum_{i=1}^{p} b_{2 i} \operatorname{Inba}_{t-i}+\sum_{i=1}^{p} c_{2 i} \text { In int }_{t-i}+\sum_{i=1}^{p} d_{2 i} \operatorname{Ininf}_{t-i}+u_{2 t}
\end{aligned}
$$

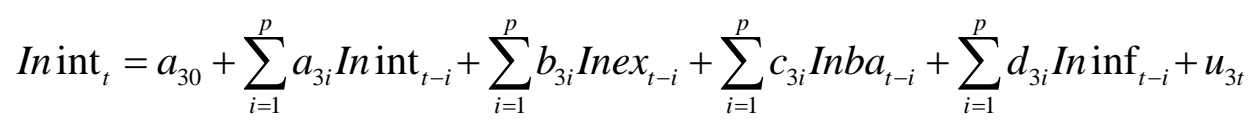

$$
\begin{aligned}
& \text { In } \text { inf }_{t}=a_{40}+\sum_{i=1}^{p} a_{4 i} \operatorname{Ininf}_{t-i}+\sum_{i=1}^{p} b_{4 i} \text { Inint }_{t-i}+\sum_{i=1}^{p} c_{4 i} \text { Inex }_{t-i}+\sum_{i=1}^{p} d_{4 i} \text { Inb }_{t-i}+u_{4 t}
\end{aligned}
$$

Where: ba (bank asset), ex (exchange rate), inf (inflationary rate) and int (interest rate). The VAR (P) above is a four-dimension specification and it is plausible to represent it in a compacted form

$$
y_{t}=a_{0}+a_{1} y_{t-1}+\ldots+a_{p} y_{t-p}+u_{t}
$$

Where y is vector of four dimension log dependent variables (ba, ex, int and inf). Then equation 3.2 with lag or backward shift operator can be expressed as.

$$
\begin{aligned}
& y_{t}=a_{0}+a_{1} y_{t-1}+\ldots+a_{p} y_{t-p}+u_{t} \\
& y_{t}=a_{0}+a_{1} L y_{t}+\ldots+a_{p} L^{P} y_{t}+u_{t} \\
& y_{t}-a_{1} L y_{t}-\ldots-a_{p} L^{P} y_{t}=a_{0}+u_{t} \\
& \left(1-a_{1} L y_{t}-\ldots-a_{p} L^{P}\right) y_{t}=a_{0}+u_{t} \\
& L(a) y_{t}=a_{0}+u_{t} \\
& \sum_{i=1}^{p} 1-L^{p} a_{p}=1
\end{aligned}
$$

Equation 3.8 shows that all the roots of the VAR polynomial rest on the complex cycle, meaning that the VAR system is not ergordic and all the variables in their log form are I(1) and therefore not stationary. The nonstationary VAR (P) needs to be transformed and as usual, we propose a VEC representation as expressed below.

$$
\Delta y_{t}=a_{0}+\pi y_{t-1}+\ldots+\sum_{i=1}^{p} a_{i} \Delta y_{t-p}+e_{t}
$$


By assumption:

Ashamu Sikiru Oyerinde

$\operatorname{Rank}(\pi)=m<k$, therefore, there is existence of cointegration and $\pi$ can be decompose into adjustment parameter $\alpha$ and long run coefficient $\beta^{\prime}$. Then, equation 3.9 becomes

$\Delta y_{t}=a_{0}+\alpha \beta^{\prime} y_{t-1}+\ldots+\sum_{i=1}^{p} a_{i} \Delta y_{t-p}+e_{t}$

Like Johansen (1980), we employed trace statistic to obtain the rank of the cointegration. The statistic is specified as follows.

$l i k_{t r}=-(T-P)-\sum_{i=1+m}^{p} \operatorname{In}\left(1-\lambda_{i}\right)$

Where: $\lambda_{i}=\lambda_{1}, \ldots, \lambda_{p}, \lambda_{1}>\lambda_{2}>\ldots>\lambda_{p}$ are the Eigen values and the Eigen vectors show the cointegration rank.

\subsection{Data Source}

The data for this study are secondary and are were sourced from the CBN annual statistical bulletin over the period of 1980 to 2015

4. Results

\subsection{Descriptive Statistics Results}

The descriptive statistics results are based on values of the mean, standard deviation, skewness, kurtosis and Jaque-Bera. These values are presented in table 1 below.

Table 1 Result of Descriptive Statistics on EX, INF, INT and TOT ASS (1980-2015)

\begin{tabular}{lcccc}
\hline \hline & EX & INF & INT & TOT ASS \\
\hline Mean & 11.44389 & 19.39667 & 21.24750 & 6004.744 \\
\hline Minimum & -21.95000 & 3.230000 & 9.500000 & 18.45630 \\
\hline Std. Dev. & 13.88579 & 17.29469 & 5.895561 & 9147.837 \\
\hline Skewness & 0.626376 & 1.617202 & -0.057698 & 1.325447 \\
\hline Kurtosis & 4.423916 & 4.595930 & 3.232494 & 3.167121 \\
\hline Jarque-Bera & 5.395383 & 19.51254 & 0.101055 & 10.58275 \\
\hline Probability & 0.067361 & 0.000058 & 0.950728 & 0.005035 \\
\hline
\end{tabular}

Source: Author's Computation using E-views Window 9

The mean values of exchange rate, inflation interest rate and total asset of banks in table 1 are about 11.44, 19.40, 21.25 and 6004.74. It appears that all these values are positive. This an indication that these variables do not decrease throughout the period of investigation. The standard deviation of these variables are 13.89, 17.29, 5.90 and 9147.84 respectively for EX, INF, INT and TOT ASS. Looking at these values, it shows that total asset has the highest standard deviation implying that it likely going to be the most volatile. Table 1 also shows that only interest rate is negatively skewed and as they asymmetric in nature. In the same token, we discover that the kurtosis values of the exchange rate and inflation are in excess of three, meaning that they all leptokurtic, while 
Ashamu Sikiru Oyerinde

interest rate and total asset are approximally three. Meaning they are mesokurtic. However, the probabilities of the Jarque-Bera statistics show that exchange rate interest rate and total asset are normally distributed while inflation does not follow a normal distribution.

\subsection{Unit Root Test}

Table 3: The Result of Unit Root Test on EX, INF, INT and TOT ASS

\begin{tabular}{llll}
\hline Variable & ADF Stat & $5 \%$ CV & P.V \\
\hline EX & -4.934 & -2.95 & 0.0003 \\
\hline $\mathrm{D}(\mathrm{EX})$ & -6.76 & -2.95 & 0.0000 \\
\hline $\mathrm{INF}$ & -2.99 & -2.95 & 0.0458 \\
\hline $\mathrm{D}(\mathrm{INF})$ & -5.66 & -2.95 & 0.0000 \\
\hline $\mathrm{INT}$ & -2.96 & -2.95 & 0.0458 \\
\hline $\mathrm{D}$ (INT) & -6.64 & -2.95 & 0.0000 \\
\hline TOT ASS & 0.97 & -2.95 & 0.9953 \\
\hline D(TOT ASS) & -2.10 & -2.95 & 0.2475 \\
\hline
\end{tabular}

Source: Author's computation using E-view 9

From the above table, it is seen that at level exchange rate, inflation, and interest rate are stationary while the null holds for total asset that the series of total asset is not stationary or has a unit root. In the same token, at first difference exchange rate, inflation, and interest rate are stationary while total asset is not stationary.

\subsection{Test of Cointegration on the Variables EX, INF, INT and TOT ASS}

The cointegration technique introduced by Johansen was adopted in this study. The results however are reported in table 4

Table 4 Cointegration Test Result on EX, INF, INT and TOT ASS

\begin{tabular}{ccccc}
\hline \hline $\begin{array}{c}\text { Hypothesized } \\
\text { No. of CE(s) }\end{array}$ & Eigenvalue & $\begin{array}{c}\text { Trace } \\
\text { Statistic }\end{array}$ & $\begin{array}{c}\text { 0.05 } \\
\text { Critical Value }\end{array}$ & Prob.*** \\
\hline \hline None * & 0.597136 & 69.61549 & 63.87610 & 0.0152 \\
At most 1 & 0.475563 & 38.70421 & 42.91525 & 0.1239 \\
At most 2 & 0.232552 & 16.75957 & 25.87211 & 0.4331 \\
At most 3 & 0.204070 & 7.760295 & 12.51798 & 0.2719 \\
\hline \hline
\end{tabular}

Source: Author's computation using E-view 9

Table 4 reports the results of the trace test and maximum Eigen test in panel A and B respectively. The highest Eigen value is about 0.60 , meaning that each of the Eigen values is less unity. This result indicates that the system is stable and cointegration test can be conducted. The trace statistic under the null hypothesis of no cointegration is 69.62 while the corresponding critical value at 5 percent is 63.88 . This suggests that the null of no cointegration is rejected. Also, the trace statistic under the null hypothesis of one cointegrating equation is 38.70 associating with critical value 42.92 . This means the hypothesis of one cointegrating vector cannot be rejected. Thus, the trace test indicates one cointegrating vector and two cointegrating ranks. Therefore, there is evidence of cointegration or long run relationship between exchange rate, inflation, interest rate and total asset of banks. 
Table 5 Results of Short Run Relationship and ECM Coefficient

\begin{tabular}{lrrrr}
\hline Regressor & ntCoefficient & Std. Error & t-Statistic & \multicolumn{1}{l}{ Prob. } \\
\hline ECM(-1) & -0.001172 & 0.006732 & -0.174072 & 0.8625 \\
\hline DTOT ASS(-1) & 0.895007 & 0.261394 & 3.423974 & 0.0012 \\
\hline DEX(-1) & 0.159291 & 0.331641 & 0.480311 & 0.6330 \\
\hline DINF(-1) & -0.462181 & 0.324225 & -1.425497 & 0.1600 \\
\hline DINT(-1) & 0.439379 & 0.290755 & 1.511163 & 0.1368 \\
\hline C & 10.09596 & 35.91628 & 0.281097 & 0.7798 \\
\hline
\end{tabular}

Source: Author's computation using E-view 9

Note that $*$ and $* *$ imply significance at $1 \%$ and $5 \%$ respectively, the critical t- statistics @ 1\% and 5\% are 2.70 and 1.67 respectively. The degree of freedom is 33 .

The ECM coefficient -0.001 or 0.1 percent as shown in table 5 has the right theoretical sign and significant at 5 percent. This means that any disequilibrium in the long run can be corrected at the rate of 0.1 percent. Also, these results show that there is long run influence or causality running from exchange rate interest rate and inflation to total asset. The short run dynamic results reveal that has. Meanwhile exchange rate and inflation have significant relationship with total asset.

5. Conclusion and Recommendation

Conclusively, recession has a negative significant relationship with bank performance in Nigeria. And on this note, it is recommended that monetary authority should formulate policies that will reduce the negative impact of recession on banks' performance since the Nigeria economy is bank driven.

\section{References}

Altunbas, Yener, Simone Manganelli, and David Marques-Ibanez. (2012). "Bank Risk during the Financial Crisis: Do business models matter?" Bangor Business School, Prifysgol Bangor University (Cymru / Wales) Working Papers 12003

Aubuchon, Craig P., and David C Wheelock. (2010). "The geographic distribution and characteristics of U.S. bank failures, 2007-2010: do bank failures still reflect local economic conditions?” Federal Reserve Bank of St. Louis Review, , (Sep): 395-415.

Beltratti, Andrea, and Ren M. Stulz. (2012). "The credit crisis around the globe: Why did some banks perform better?" Journal of Financial Economics, 105(1): 1-17.

Berger, Allen N., and Christa H.S. Bouwman. (2013). "How does capital aff ect bank performance during financial crises?" Journal of Financial Economics, 109(1): 146-176..

Cole, Rebel Allen, and Lawrence White. (2012). "D'ej'a Vu All Over Again: The Causes of U.S. Commercial Bank Failures This Time Around." Journal of Financial Services Research, 42(1): 5-29.

DeYoung, Robert, and Gkhan Torna. (2013). "Nontraditional banking activities and bank failures during the financial crisis." Journal of Financial Intermediation, 22(3): 397-421.

Fahlenbrach, Rdiger, and Ren M. Stulz. (2011). "Bank CEO incentives and the credit crisis." Journal of Financial Economics, 99(1): 11-26.

Fahlenbrach, Rdiger, Robert Prilmeier, and Ren M. Stulz. (2012). "This Time Is the Same: Using Bank Performance in 1998 to Explain Bank Performance during the Recent Financial Crisis.” Journal of Finance, 67(6): 2139-2185.

Golden, Sam and Harry (1993): The Ten Commandments of Commercial Credit. The Cs of good and bad 
loans. Journal of Commerial Bank Leading

Ashamu Sikiru Oyerinde

Laeven, Luc, and Ross Levine. (2009). "Bank governance, regulation and risk taking.” Journal of Financial Economics, 93(2): 259-275

Peek, Joe, and Eric Rosengren. (1997). "How well capitalized are well-capitalized banks?" New England Economic Review, , (Sep): 41-50.

Ratnovski, Lev, and Rocco Huang. (2009). "Why are Canadian Banks More Resilient?" IMF Working Paper, 1-19.

Wheelock, David C, and Paul W. Wilson. (2000). "Why do Banks Disappear? The Determinants of U.S. Bank Failures and Acquisitions." The Review of Economics and Statistics, 82(1): 127-138.

Waweru, N.M. and Kalani, V.M. (2009). Commercial Banking Crises in Kenya: Causes and Remedies. African Journal of Accounting, Economic, Finance and Banking Research, (N), 12-33.

McNulty, J., Akhigbe, A. \&Verbrugge, J.(2001). Small Bank loan quality in a Deregulated Environment: The information advantage hypothesis.Journal of Economics and Business, 53, 325-39.

Samuel, K.S.(2011): Lending practices and causes of loan defaults. Leading practices and causes of loan default among some selected banks in Ghana.

\section{Copyrights}

Copyright for this article is retained by the author(s), with first publication rights granted to the journal. 